\title{
Apathy in geriatric cancer research
}

With an estimated 60 percent of American cancer patients now over age 65 , and a rapidly graying population, the National Institutes of Health (NIH) has put out calls for research into how to better detect cancer and tailor chemotherapy regimens in this group. But so far, about a year into the effort, few researchers have submitted grant applications: Diane Bronzert, of the National Cancer Institute's (NCI) Division of Cancer Treatment and Diagnosis, has received only two submissions-neither of which has been funded-for a program announced last May seeking better pharmacokinetic and pharmacodynamic information on chemotherapies in the aged.

So why haven't there been more? Bronzert believes research in the area is hindered by multiple factors, including the difficulty of making a hypothesis-driven application with little available historical data, but she admits, "I was disappointed with this response because we pushed [the program] hard at the ASCO clinical meeting last year."

At its 1998 meeting, ASCO (the American Society of Clinical Oncology) highlighted the difficulties of studying cancer therapies in the elderly. Older patients have traditionally been underrepresented in trials-only about 1.5 percent of those over 65 with cancer participate. Seniors are often reluctant, fearing new therapy that might be extremely toxic; or they and their oncologists may hesitate, believing their treatment will not be covered by Medicare or insurance (Nature Med. 4, 992; 1998).

Drug companies have avoided studying their products in the aged, because those patients' co-morbidities and multiple-drug regimens make them poor candidates for getting the best results. "If you want to prove a drug is useful, you choose the healthiest possible individual to give yourself a chance," says Michael O'Connell, a Mayo Clinic oncologist and chair of the NCI-sponsored North Central Treatment Group.

The North Central Group and Mayo Clinic plan to submit a grant application to NIH this fall, seeking some of the several million dollars put aside by the NCI and the National Institute on Aging. Last October, the agencies asked for new treatment strategies for the over-65 age group and North Central hopes to begin studies in early 2000, according to
O'Connell. Mayo is also developing its own program in geriatric oncology. "We can see in the future that the majority of patients we're going to be serving are going to be in this elderly population, "says O'Connell.

Meanwhile, some members of Congress are trying to ensure that seniors' clinical trial care costs are covered by Medicare. At an August briefing for Senate and House staff, ASCO president Joseph Bailes revealed that many oncologists have begun simply to submit treatment bills, and are already getting reimbursed by Medicare. Thus, it would not be so costly to formalize the coverage, he claims. In fact, Medicare coverage bills have been introduced in both houses of Congress, and may pass as part of "patients' rights" proposals in October. This is despite the fact that President Clinton asked for a three-year demonstration program in which Medicare would pay for clinical trials in FY99, 00 and 01, which has not been done. The Congressional Budget Office, has estimated that this three-year trial period alone would have added $\$ 750$ million to the cost of the Medicare program.

Alicia Ault, Washington DC

\section{German cutbacks hurt science}

In an effort to combat Germany's growing national deficit, the country's new Treasury Secretary, Hans Eichel, has announced a plan to slash next year's federal budget by DM30 billion (US $\$ 16.4$ billion). This burden, Eichel demands, must be shouldered by all government departments equally, and for the Ministry of Science this could mean cutting expenses by five percent, effectively reversing last year's budget raise of over six percent, which had ended a decade of stagnation under the former Kohl government.

Chancellor Gerhard Schröder has defended the cost-saving measures, known as "Eichel-Sparpacket," and ruled out any exceptions, although many scientists hope that maneuverings by Science Secretary Edelgard Bulmahn will pay dividends and that the sci-

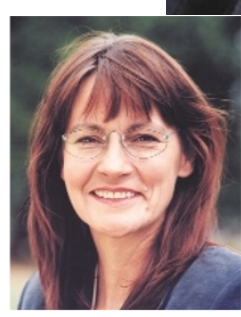
Edelgard Bulmahn ence budget will only decrease by 2.3 percent from this year's DM14.93 billion. Schröder has not commented on promises he made during last year's election campaign to double investments within five years, (Nature Med. 5, 253; 1999).

Close inspection of the allocations to science reveal that DM550 million in grant money (BAföG) will be paid by the federal government's credit institute, Deutsche Ausgleichsbank. This, in essence, hides money that benefits science by moving it outside the Science Minstry's budget. And some research areas may still see a modest increase: biotechnology funding is set to rise 5.4 percent to DM195 million, public health and medical research will increase 1.7 percent to DM178 million and molecular medicine will gain a 1.4 percent increase to DM75 million.

But even with Bulmahn's 'creative accounting', it appears that the country's premier scientific organizationsthe Max-Planck-Gesellschaft (MPG) and the Deutsche Forschungsgemeinschaft (DFG) - will have to manage on only a three percent increase in federal money. And the cuts do not bode well for the recent proposal by the DFG to make an additional DM400 million available over the next five years for genome research.

"I'll be in real trouble when they give much less than the five percent promised," MPG president Hubert Markl admitted to Nature Medicine, referring to the task of rebuilding the scientific infrastructure in former East Germany, which is far from complete. Despite the difficulties, Markl still feels that science and research is a priority with the new government, a sentiment echoed by a DFG spokesperson, who claims that science is faring "reasonably well in comparison to other departments."

At present, almost one quarter of the government's tax revenue is spent on interest payments. The cuts are expected to win parliamentary approval in late fall without major changes. A recent poll found that 80 percent of Germans support the plan.

Michael Simm, Offenburg 